\title{
In vitro Evaluation of Rice Genotypes for Brown Plant hopper (Nilaparvata lugens Stal.) Resistance
}

\author{
Archana Shori*, D.K. Rana, M.G. Sable and Poonam Kumari \\ Department of Entomology, Indira Gandhi Krishi Vishwavidyalaya, \\ College of Agriculture, Raipur- 492012, Chhattisgarh, India \\ *Corresponding author
}

\begin{tabular}{|c|c|}
\hline & A B S T R A C T \\
\hline & ouse experiment was conducted at Department of Entomology, IGKV, Raipur \\
\hline Keywords & $\begin{array}{l}\text { (Chhattisgarh), during } 2014-15 \text { to evaluate different rice genotypes for brown planthopper } \\
\text { (BPH) resistance. A total of } 392 \text { rice genotypes were evaluated, of which } 58 \text { were from }\end{array}$ \\
\hline Rice, BPH, & IRRI, 78 were aromatic types and rest 256 represented the local germplasm. Of 58 rice \\
\hline Nilaparvata lugens. & 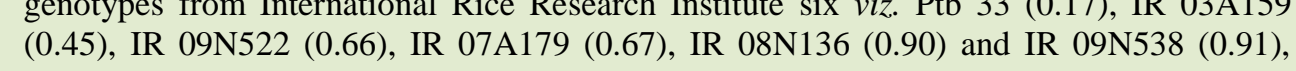 \\
\hline Article Info & $\begin{array}{l}\text { were found to be highly resistant to BPH while } 32.7 \% \text { were resistant. Among the } 78 \\
\text { aromatic rice genotypes tested for BPH reaction, eight were identified as resistant viz. Lua }\end{array}$ \\
\hline $\begin{array}{l}\text { Accepted: } \\
\text { 20 February } 2017 \\
\text { Available Online: } \\
10 \text { March } 2017\end{array}$ & $\begin{array}{l}\text { Nhe Den (1.66), Bong Cay (1.67), KDML } 105 \text { (1.94), UPR-2828-7-2-1 (2.39), IR 754286- } \\
3 \text { (2.56), Improved Pusa Basmati } 1 \text { (2.79), Shyamjeera (3.00) and Longku Labat (3.00), } \\
\text { while six as moderately resistant and rest as susceptible. In another set of experiment } \\
\text { conducted with } 265 \text { rice germplasm, only } 11.32 \% \text { exhibited resistance to BPH, lowest } \\
\text { plant damage score being recorded with } 579004(1.40) \text {, followed by } 464205(1.50) \text { and }\end{array}$ \\
\hline & (1.50) while 55 were moderately resistant and rest were susceptible \\
\hline
\end{tabular}

\section{Introduction}

Rice (Oryza sativa L.) is a primary staple food crop for billions of people worldwide. India has the biggest area under rice cultivation, as it is one of the principal food crops. During the kharif marketing season 2012-13, Chhattisgarh recorded production of over 7.12 MT of paddy worth Rs 11,000 crore and was crowned as the rice bowl of India (FAO 2013). However, production of this crop is greatly hampered by several biotic and abiotic factors. Among the biotic factors brown planthopper (BPH), Nilaparvata lugens (Stal.) (Homoptera: Delphacidae) is consisted as one of the most important insect pest in rice. It was first reported as a sporadic pest of rice in 1927 around Tenali in Guntur district of Andhra Pradesh, India (Tirumalarao, 1950). Brown planthopper infest the rice crop at all stages of plant growth. The nymphs and adults of the insect are usually found at the bases of the canopy, where area is shady and humidity is high. As a result of feeding by both nymphs and adults at the base of the tillers, plants turn yellow and dry up rapidly. At early infestation, round, yellow patches appear, which soon turn brownish due to the drying up of the plants. The loss in grain yield due to this insect range from $10 \%$ in moderately affected fields to $70 \%$ in those severely affected. The 
damage to the standing crop sometimes reached $100 \%$. Farmers mostly depend on chemical pesticides for the control of this pest. Though insecticide application is providing immediate control, ill effects like resurgence, secondary out break and development of resistance to insecticides are most common with BPH. Hence, cultivation of resistant rice varieties is the most economical and efficient method for the management of BPH (Renganayaki et al., 2002).

For over 50 years, the development of host plant resistance against these insect has been a major focus at the International Rice Research Institute (IRRI) and other national and international rice research canters (Peng and Khush, 2003; Brar et al., 2009; Jena and Kim, 2010). Standard seed box screening test has been effectively used for screening resistant lines (Heinrichs et al., 1985).

Chhattisgarh has relatively more virulent population of $\mathrm{BPH}$. The international material which is being screened worldwide for BPH resistance may have the good source of host plant resistance against this pest. Hence the study was conducted to know the reaction of rice genotypes against Raipur $\mathrm{BPH}$ population.

\section{Materials and Methods}

Fifty eight entries received from IRRI (International Rice Research Institute) under IRBPHN (International Rice Brown Planthopper Nursery), 78 (Seventy Eight) aromatic rice genotypes provided by CANP (Aromatic Network Project) under DBT (Department of Biotechnology) and 265 rice germplasm were used for this study. The entries were evaluated by adopting internationally accepted standard seed box screening technique of IRRI. The rice varieties Ptb 33 and TN 1 were taken as resistant and susceptible check respectively.

\section{Rearing of insect}

Initially BPH population was collected from the rice field. The collected insects were reared and maintained in 45 days old host plants in separate culture room which was protected with wire mesh. The test and check genotypes were pre-germinated in petri dishes (10 $\mathrm{cm}$ diameter). Wooden box of standard size $(50 \times 40 \times 7 \mathrm{~cm})$ was filled with fine wet soil and levelled properly.

Each test entry was sown in single row containing 20 pre-germinated seeds with a spacing of $2 \times 1 \mathrm{~cm}$ including in middle separate rows of resistant check PTB33 and susceptible check TN1 were sown on borders and in between the rows of test entries respectively. After seven days of sowing, the seedling were infested with second and third instar nymphs of BPH at the rate of eight to ten nymphs per seedling constitutes an optimum population to differentiate the resistant and susceptible lines. The final damage rating was taken when the insect killed more than 90 per cent of TN 1 seedlings. The reactions were recorded on a 0-9 scale (IRRI - IRTP, 1975) as shown in Table 1.

\section{Results and Discussion}

The indiscriminate use of chemical pesticides with the aim to maximize crop productivity has witnessed severe consequences to environment. It not only leads to harmful effect on soil micro and micro flora but also greatly increases the chances of deleterious effect of residual toxicity on human and animal health. The demand for pesticide free food urgently requires the alternatives to the chemical pesticides. The use of resistant genotypes presents one of the viable options to this. With this aim the present work was focussed to screen the rice genotypes resistant to $\mathrm{BPH}$. A total of 58 rice genotypes were collected from International Rice Research 
Institute (IRRI) and screened for resistance to BPH. It was observed that the IRRI has a wide range of resistance sources for $\mathrm{BPH}$ although rice genotypes exhibited varied response to the Raipur BPH population. Table 2 enlists the average plant damage score of rice genotype entries from IRRI (IRBPHN). The results of 58 IRBPHN screening trials showed that the rice genotypes viz. Ptb33 (0.17), IR 03A159 (0.45), IR 09N522 (0.66), IR 07A179 (0.67), IR 08N136 (0.90) and IR 09N538 (0.91) were highly resistant. The $\mathrm{BPH}$ resistance of genotype Ptb33 has already been cited (Jairin et al., 2007).

The average plant damage score of $32.7 \%$ of rice genotypes ranged from 1.00 to 3.00 and were categorized as resistant ones. The genotype IR 09A136 showed the least plant damage score (1.00) followed by IR 06M144 (1.13) and IR 06M143 (1.18).

In comparison to IRRI rice genotypes, aromatic rice and local genotypes were less resistant to $\mathrm{BPH}$. Of 78 aromatic genotypes tested, only eight were categorized as resistant, Lua Nhe Den recorded the lowest plant damage score (1.66) followed by Bong Cay (1.67) and KDML 105 (1.94) while six were moderately resistant (Table 3 ).

Among 265 local rice germplasm tested, thirty genotypes were categorized as resistant while only $20.7 \%$ were moderately resistant. The genotype 579004 surpassed others with the lowest plant damage score (1.40) followed by 464205,578983 (1.50) (Table 4).

Table.1 Standard for rating damage by brown planthopper (IRRI-IRTP, 1975)

\begin{tabular}{|c|c|c|}
\hline Grade of damage & Rating* & Symptom \\
\hline 0 & HR & No visible damage \\
\hline 1 & $\mathrm{R}$ & Partial yellowing at first leaf \\
\hline 3 & MR & First and second leaves partially yellow \\
\hline 5 & MS & Pronounced yellowing and some stunting \\
\hline 7 & $\mathrm{~S}$ & Wilting and severe stunting \\
\hline 9 & HS & All test plants dead \\
\hline
\end{tabular}

*HR = highly resistant; $\mathrm{R}=$ resistant; $\mathrm{MR}=$ moderately resistant; MS = moderately susceptible; $\mathrm{S}=$ susceptible; $\mathrm{HS}=$ highly susceptible 
Table.2 Average plant damage score of rice genotypes (IRBPHN) against BPH, Nilaparvata lugens (Stal.)

\begin{tabular}{|c|c|c|c|}
\hline S. No. & Designation & $\begin{array}{c}\text { *Average plant damage } \\
\text { score }\end{array}$ & $* *$ Rating \\
\hline 1 & Ptb 33 & 0.17 & HR \\
\hline 2 & IR 03A159 & 0.45 & $\mathrm{HR}$ \\
\hline 3 & IR 09N522 & 0.66 & $\mathrm{HR}$ \\
\hline 4 & IR 07A179 & 0.67 & HR \\
\hline 5 & IR $08 N 136$ & 0.90 & $\mathrm{HR}$ \\
\hline 6 & IR 09N538 & 0.91 & HR \\
\hline 7 & IR 09A136 & 1.00 & $\mathrm{R}$ \\
\hline 8 & IR 06M144 & 1.13 & $\mathrm{R}$ \\
\hline 9 & IR $06 \mathrm{M} 143$ & 1.18 & $\mathrm{R}$ \\
\hline 10 & IR 08 N195 & 1.36 & $\mathrm{R}$ \\
\hline 11 & IR 06M150 & 1.47 & $\mathrm{R}$ \\
\hline 12 & IR 06N155 & 1.64 & $\mathrm{R}$ \\
\hline 13 & IR 04A115 & 1.69 & $\mathrm{R}$ \\
\hline 14 & IR $05 N 419$ & 1.89 & $\mathrm{R}$ \\
\hline 15 & IR 10A110 & 1.89 & $\mathrm{R}$ \\
\hline 16 & IR $05 N 170$ & 1.93 & $\mathrm{R}$ \\
\hline 17 & IR 06N234 & 2.05 & $\mathrm{R}$ \\
\hline 18 & TME80518 & 2.08 & $\mathrm{R}$ \\
\hline 19 & IR 10F203 & 2.25 & $\mathrm{R}$ \\
\hline 20 & IR 06N119 & 2.32 & $\mathrm{R}$ \\
\hline 21 & IR 10A155 & 2.38 & $\mathrm{R}$ \\
\hline 22 & IR 10F388 & 2.61 & $\mathrm{R}$ \\
\hline 23 & IR 09A152 & 2.63 & $\mathrm{R}$ \\
\hline 24 & IRRI 151 & 2.67 & $\mathrm{R}$ \\
\hline 25 & Pokkali & 3.00 & $\mathrm{R}$ \\
\hline 26 & IR 10 F336 & 3.01 & MR \\
\hline 27 & IR 09A228 & 3.22 & MR \\
\hline 28 & RP 4964-100-10-9-5-1-1 & 3.24 & MR \\
\hline 29 & IR $09 \mathrm{~N} 142$ & 3.28 & MR \\
\hline 30 & IR $10 \mathrm{~N} 269$ & 3.39 & MR \\
\hline 31 & IR 10N304 & 3.95 & MR \\
\hline 32 & IR 09F436 & 4.38 & MR \\
\hline 33 & IR 13146-45-2-3 & 4.54 & MR \\
\hline 34 & IR 09N500 & 4.97 & MR \\
\hline
\end{tabular}

* Average plant damage score based on 3 replications 
Table.3 Average plant damage score of aromatic rice genotypes against $\mathrm{BPH}$, Nilaparvata lugens (Stal.)

\begin{tabular}{|c|c|c|c|c|c|}
\hline $\begin{array}{c}\text { S. } \\
\text { No. }\end{array}$ & $\begin{array}{c}\text { Accession } \\
\text { No. }\end{array}$ & Designation & Source & $\begin{array}{c}* \text { Average } \\
\text { plant damage } \\
\text { score } \\
\end{array}$ & **Rating \\
\hline 1 & CANP 421 & Lua Nhe Den & VIETNAM/DRR & 1.66 & $\mathrm{R}$ \\
\hline 2 & CANP 406 & Bong Cay & VIETNAM/DRR & 1.67 & $\mathrm{R}$ \\
\hline 3 & CANP 121 & KDML 105 & THAILAND/CBT & 1.94 & $\mathrm{R}$ \\
\hline 4 & CANP 521 & UPR-2828-7-2-1 & PANTNAGAR & 2.39 & $\mathrm{R}$ \\
\hline 5 & CANP 535 & IR 75428-6-3 & IRRI/DRR & 2.56 & $\mathrm{R}$ \\
\hline 6 & CANP 309 & Improved Pusa Basmati 1 & IARI/DRR & 2.79 & $\mathrm{R}$ \\
\hline 7 & CANP 168 & Shyamjeera & RPR & 3.00 & $\mathrm{R}$ \\
\hline 8 & CANP 422 & Longku Labat & INDONESIA/DRR & 3.00 & $\mathrm{R}$ \\
\hline 9 & CANP 496 & JGL 1798 & JGL/DRR & 3.11 & MR \\
\hline 10 & CANP 510 & Kh.Sakani & DRR & 3.24 & MR \\
\hline 11 & CANP 410 & Daw Leuang & THAILAND/DRR & 3.25 & MR \\
\hline 12 & CANP 339 & - & - & 3.33 & MR \\
\hline 13 & CANP 412 & Guinata & PHILIPPINES/DRR & 3.67 & MR \\
\hline 14 & CANP 549 & IET 18033 (RP 3644-9-5-3-2) & DRR & 4.86 & MR \\
\hline
\end{tabular}

* Average plant damage score based on 3 replications

Table.4 Average plant damage score of rice germplasm against BPH, Nilaparvata lugens (Stal.)

\begin{tabular}{llll}
\hline \hline S. No. & IC. No. & \multicolumn{2}{c}{$\begin{array}{c}* \text { Average plant damage } \\
\text { score }\end{array}$} \\
\hline 1 & 579004 & 1.40 & $\mathrm{R}$ \\
2 & 464205 & 1.50 & $\mathrm{R}$ \\
3 & 578983 & 1.50 & $\mathrm{R}$ \\
4 & 578984 & 1.70 & $\mathrm{R}$ \\
5 & 578969 & 1.80 & $\mathrm{R}$ \\
6 & 578979 & 1.80 & $\mathrm{R}$ \\
7 & 465043 & 1.90 & $\mathrm{R}$ \\
8 & 578674 & 2.00 & $\mathrm{R}$ \\
9 & 578149 & 2.10 & $\mathrm{R}$ \\
10 & 577517 & 2.30 & $\mathrm{R}$ \\
11 & 577293 & 2.40 & $\mathrm{R}$ \\
12 & 578401 & 2.40 & $\mathrm{R}$ \\
13 & 578972 & 2.40 & $\mathrm{R}$ \\
14 & 578717 & 2.50 & $\mathrm{R}$ \\
15 & 579011 & 2.50 & $\mathrm{R}$ \\
\hline 16 & 577390 & 2.60 & $\mathrm{R}$ \\
17 & 578443 & 2.60 & $\mathrm{R}$ \\
18 & 578992 & 2.60 & $\mathrm{R}$ \\
19 & 464884 & 2.70 & $\mathrm{R}$ \\
20 & 577663 & 2.80 & $\mathrm{R}$ \\
21 & 578417 & 2.80 & $\mathrm{R}$
\end{tabular}




\begin{tabular}{|c|c|c|c|}
\hline 22 & 466399 & 2.81 & $\mathrm{R}$ \\
\hline 23 & 578017 & 2.90 & $\mathrm{R}$ \\
\hline 24 & 578144 & 2.90 & $\mathrm{R}$ \\
\hline 25 & 464129 & 3.00 & $\mathrm{R}$ \\
\hline 26 & 578102 & 3.00 & $\mathrm{R}$ \\
\hline 27 & 578128 & 3.00 & $\mathrm{R}$ \\
\hline 28 & 578137 & 3.00 & $\mathrm{R}$ \\
\hline 29 & 579022 & 3.00 & $\mathrm{R}$ \\
\hline 30 & 578927 & 3.00 & $\mathrm{R}$ \\
\hline 31 & 578721 & 3.10 & MR \\
\hline 32 & 578406 & 3.11 & MR \\
\hline 33 & 578957 & 3.11 & MR \\
\hline 34 & 579010 & 3.12 & MR \\
\hline 35 & 578527 & 3.13 & MR \\
\hline 36 & 578329 & 3.18 & MR \\
\hline 37 & 578131 & 3.22 & MR \\
\hline 38 & 578135 & 3.22 & MR \\
\hline 39 & 578358 & 3.22 & MR \\
\hline 40 & 579035 & 3.25 & MR \\
\hline 41 & 466603 & 3.26 & MR \\
\hline 42 & 579030 & 3.31 & MR \\
\hline 43 & 466609 & 3.40 & MR \\
\hline 44 & 463306 & 3.50 & MR \\
\hline 45 & 578413 & 3.50 & MR \\
\hline 46 & 463854 & 3.55 & MR \\
\hline 47 & 578967 & 3.55 & MR \\
\hline 48 & 578139 & 3.58 & MR \\
\hline 49 & 578737 & 3.60 & MR \\
\hline 50 & 579034 & 3.60 & MR \\
\hline 51 & 578459 & 3.63 & MR \\
\hline 52 & 578965 & 3.66 & MR \\
\hline 53 & 463905 & 3.72 & MR \\
\hline 54 & 578680 & 3.78 & MR \\
\hline 55 & 577478 & 3.80 & MR \\
\hline 56 & 578148 & 3.88 & MR \\
\hline 57 & 579036 & 3.90 & MR \\
\hline 58 & 463018 & 4.00 & MR \\
\hline 59 & 462531 & 4.00 & MR \\
\hline 60 & 577788 & 4.00 & MR \\
\hline 61 & 578500 & 4.00 & MR \\
\hline 62 & 578914 & 4.00 & MR \\
\hline 63 & 579012 & 4.00 & MR \\
\hline 64 & 579013 & 4.00 & MR \\
\hline 65 & 578444 & 4.05 & MR \\
\hline 66 & 578371 & 4.16 & MR \\
\hline
\end{tabular}

*Average plant damage score based on 3 replications 
Same kind of results was reported by Ali et al. (2012) the donors like Mudgo, ASD7, Raghu hematic, Babawee, ARC10550, Swarnalatha, T12, Chin saba and Balamawee showed no resistance to $\mathrm{BPH}$. Most of the genotypes which were proven as resistant to $\mathrm{BPH}$ in earlier by different parts of the world, were found to be susceptible in our screening at Chhattisgarh, Bharat. Bhimrao et al., (2005) have screened 4324, 50423, 38,168, and 121 entries, respectively and stated 20, $555,5,7$ and 3 varieties under resistant category. This study indicated that a major portion of the tested rice genotypes are resistant to the $\mathrm{BPH}$ population.

\section{References}

Ali, M.P., Alghamdi, S.S., Begum, M.A., Anwaruddin, A.B.M., Alam, M.Z. and Huang, D.C. 2012. Screening of Rice Genotypes for Resistance to the Brown Planthopper, Nilaparvata lugens (Stal.). Cereal Research Communications, 40(4):502-508.

Brar, D.S., Virk, P.S., Jena, K.K., and Khush, G.S. 2009. Breeding for resistance planthoppers in rice. In: Planthoppers: New Threats to the Sustainability of Intensive Rice Production Systems in Asia, pp. 401-409. Heong, K. L. and Hardy, B. Eds., International Rice Research Institute, Los Banos, Philippines.

Bhimrao, K.G., Dubey, V.K. and Pophaly, D.J. 2005. Studies on relative degree of damage by Brown planthopper Nilaparvata lugens (Stal.) on rice genotype and its management through plant derivatives. M.Sc. (Ag.) Thesis,
Indira Gandhi Krishi Vishwavidyalaya, Raipur, p. 45.

Heinrichs, E.A., Medrana, F.G. and Rapusas, H.R. 1985. Genetic evaluation for insect resistance in rice. Los Banos, Philippines, International Rice Research Institute, $\mathrm{p}$. 356.

IRRI-IRTP. 1975. International Rice Testing Programme. Preliminary report of the first international rice brown planthopper nursery (IRBPHN). International Rice Research institute, p.7.

Jairin, J., Phengrat, K., Teangdeerith, S., Vanavichit, A., and Toojinda, T. 2007. Mapping of a broad-spectrum brown planthopper resistance gene, Bph3, on rice chromosome 6. Mol. Breeding, 19:35-44.

Jena, K.K. and Kim, S.M. 2010. Current status of brown planthopper $(\mathrm{BPH})$ resistance and genetics. Rice, 3: 161-171.

Peng, S. and Khush, G. S. 2003. Four decades of breeding for varietal improvement of irrigated lowland rice in the International Rice Research Institute. Plant Prod. Sci., 6: 157-164.

Renganayaki, K., Fritz, A.K., Sadasivam, S., Pammi, S, Harrington, S.E., McCouch, S.R., Kumar, S.M. and Reddy, A.S. 2002. Mapping and progress toward map based cloning of brown planthopper biotype 4 resistance gene introgressed from Oryza officinalis into cultivated rice, O. sativa. Crop Science, 42: 2112-2117.

Tirumalarao, V. 1950. Nilaparvata lugens (Stal.) (Fulgoridae : Homoptera) as a pest of paddy cultivation in North Madras and its control. Indian Journal Entomology, $12: 241-246$.

\section{How to cite this article:}

Archana Shori, D.K. Rana, M.G. Sable and Poonam Kumari. 2017. In vitro Evaluation of Rice Genotypes for Brown Plant hopper (Nilaparvata lugens Stal.) Resistance. Int.J.Curr.Microbiol.App.Sci. 6(3): 2547-2553. doi: https://doi.org/10.20546/ijcmas.2017.603.288 